\title{
Elections as Causes of Democratization: Southeast Asia in Comparative Perspective
}

\section{Lee Morgenbesser' and Thomas B. Pepinsky²}

\begin{abstract}
The theory of democratization by elections holds that elections - even when flawed-can, over time, have an independent causal effect on democratic transitions. Despite the recent growth of this literature, questions remain about the global scope of the argument and its structural preconditions. We show that, in Southeast Asia, elections are almost always the culmination rather than the cause of democratization, and use case materials from seven Southeast Asian countries to illustrate the mechanisms that lead from democratization to elections. Our argument has implications both for Southeast Asian democratization and for existing scholarship from other world regions.
\end{abstract}

\section{Keywords}

democratization and regime change, elections, Southeast Asia, nondemocratic regimes

\section{Introduction}

The theory of democratization by elections has quickly become a prominent explanation for how even flawed elections can advance democratic change in

\footnotetext{
'Griffith University, Queensland, Australia

${ }^{2}$ Cornell University, Ithaca, NY, USA

\section{Corresponding Author:}

Thomas B. Pepinsky, Cornell University, 322 White Hall, Ithaca, NY I4853, USA.

Email: pepinsky@cornell.edu
} 
authoritarian regimes. A burgeoning body of research has identified a robust causal relationship between repeated multiparty elections and democratization, both globally and regionally (Donno, 2013b; Edgell, Mechkova, Altman, Bernhard, \& Lindberg, 2015; Howard \& Roessler, 2006; Lindberg, 2006, 2009a). This relationship is especially prevalent in sub-Saharan Africa and Eastern Europe, but has also been studied in Latin America and the Middle East/North Africa. Despite the willingness of scholars to examine regional patterns of electoral democratization, Southeast Asia has remained almost entirely absent from this research agenda. Between 1945 and 2015, authoritarian regimes in this region oversaw 88 competitive elections, but today, only Indonesia and the Philippines are electoral democracies. What explains the persistence of authoritarianism in a region of competitive elections?

In this article, we bring Southeast Asia into conversation with the larger theoretical and empirical scholarship on democratization by elections. In doing so, we provide a novel perspective on elections and democratization in Southeast Asia that has broader implications for this research area. Drawing on process-based theories of democratization, we argue that, although it is logically possible for elections to cause democratization, elections frequently also signal the completion of a democratization process. Assessing the causal role of elections as agents of democratic change requires careful qualitative scrutiny, because the same quantitative data used to measure the effects of elections may also be used to measure the existence of democracy itself. Case materials from Southeast Asia are broadly consistent with an interpretation of democratization as a causal process that usually culminates with elections, rather than the alternative view in which elections are independent agents of change. We also show how this observation affects quantitative studies of the relationship between democratization and elections.

This argument has critical implications for existing research on the relationship between democratization and elections under authoritarianism. Conceptually, we emphasize the distinction between elections as causes of democracy and elections as features of democracy. The potential for tautology is particularly pronounced in the case of Indonesia, which we identify as a case where an election represents the endpoint rather than the starting point of democratization. Empirically, the article capitalizes on the opportunities Southeast Asia provides as a region "relatively neglected" in comparative politics (Kuhonta, Slater, \& Vu, 2008, p. 2). It profits from a long history of flawed elections in an extraordinarily diverse region, providing us with a range of insights into the conditions under which elections do or do not produce democratization. Our analysis suggests a return to preexisting findings about democratization by elections elsewhere in the world to identify the background conditions that enable elections to have democratizing effects. 
Focusing on Southeast Asia allows us to respond directly to Edgell et al. (2015), who urge scholars working in this area to delve more deeply into cases from Asia. Methodologically, the article employs both within-case historical analyses and cross-national statistical techniques to examine the relationship between flawed elections and democratization. Instead of relying solely on cross-national statistics, which has so far been the dominant approach to this question, an integrative multimethod approach provides a stronger foundation for assessing the causal effect of elections on democratization.

We begin by reviewing briefly the theory of democratization by elections, with particular focus on its specific prescriptions for achieving regime change via flawed elections. We then detail an alternative perspective on elections and democracy, highlighting the constitutive rather than causal relationship between them. The subsequent section brings our theoretical insights about process-based theories of democratization and the measurement of democracy using elections into conversation with the Southeast Asian cases. Using seven case studies and a cross-national statistical test, we find that competitive elections under authoritarianism do not increase the subsequent likelihood of democratization in the region, even though we do find such effects in a global sample. The conclusion addresses the implications of our argument for current research on elections, democratization, and region-level analysis in comparative politics.

\section{Democratization by Elections}

The central claim of democratization by elections is that elections have causal effects on regime change. In the simplest terms, elections structure political interaction and, in turn, influence political outcomes (Bratton \& van de Walle, 1997; Snyder \& Mahoney, 1999). The most explicit expression of the idea that even flawed elections in authoritarian regimes can eventually bring about democratization is offered by the contributors to Lindberg (2009a). Despite some reservations, the authors provide partial support for this theory in Latin America and the Middle East/North Africa, but especially in Eastern Europe and sub-Saharan Africa. The underlying premise is that de jure competitive elections are a venue for political competition involving not only a competition for votes but also broader competition over the rules of the political system that unfolds simultaneously and interactively (Schedler, 2002; Tsebelis, 1990). In light of the different demands held by dictators, ruling parties, and opposition groups, flawed elections become imbued with uncertainty over their outcomes. The former must make a trade-off between electoral control and electoral credibility, whereas the latter seek tangible political 
gains without conferring any benefits. Because neither actor is capable of reconciling these goals, they face a strategic dilemma. The critical point here is that, regardless of the choices made, elections have the intrinsic capacity to undermine authoritarian rule. This is based on a simple formula with roots in the classic work by Dahl (1971): The lower the costs of toleration, the greater the security of the incumbent regime; the higher the costs of repression, the greater the security of its opponents. Over time, the repetition of flawed elections increases the costs of authoritarian rule in ways conducive to democratization.

The aura of inevitability attached to authoritarian elections has made it an alluring field of enquiry. A prominent focus has been on what type of regime is sufficient for electoral democratization to take hold. Under competitive authoritarianism, dictators and ruling parties dilute the capacity of opposition parties to win office, intentionally infringe upon civil liberties, and regularly abuse state resources to create an uneven playing field. Under hegemonic authoritarianism, those same actors legally bar opposition parties from existing, violate basic civil liberties through the use of overt repression, and monopolize access to resources, media, and the law (on both subtypes, see Levitsky \& Way, 2010). Using this distinction, Howard and Roessler (2006), Brownlee (2009), and Donno (2013b) have demonstrated that electoral democratization is more likely to occur in competitive authoritarian regimes. This outcome is itself dependent upon the relative weakness of the ruling party when faced with opposition coordination (van de Walle, 2006; Wahman, 2013) and international conditionality (Donno, 2013a; Hyde, 2011; Kelley, 2012). Such conditions contribute to an environment that favors cleaner elections by raising the costs of manipulation and misconduct for dictators and ruling parties. Another notable cost of flawed elections is the possibility of mass protests, which have been highlighted for their capacity to oust these incumbent actors and trigger democratization (Beaulieu, 2014; Brancati, 2016; Bunce \& Wolchik, 2010, 2011). This is symptomatic of the risks confronting authoritarian regimes attempting the difficult task of maintaining both electoral control and electoral credibility.

A theoretically rigorous and empirically expansive body of literature finds that even flawed elections under authoritarianism "matter" for democratization. An opposing view nevertheless contends that the very same elections can aid the longevity of authoritarian regimes, especially over the long term (see Gandhi, 2015; Knutsen, Nygård, \& Wig, 2017; Miller, 2015b). In a balanced analysis of this debate, Schedler (2013) concludes that the conceptual differentiation between competitive and hegemonic authoritarianism dissolves any empirical contradiction observed in terms of regime trajectories. In his view, democratization hinges on the fact that multiparty elections make 
dictators and ruling parties dependent on other actors, thereby rendering them vulnerable to them. This is because the existence of electoral competition creates structural vulnerabilities in the form of individual and collective challengers, whereby opposition parties, regime allies, state agents, and citizens desert the dictator and ruling party (Schedler, 2013, pp. 146-149). In a similar way, Miller (2015a) argues that a track record of contestation under authoritarianism has a positive effect on democratization. Drawing on an expansive dataset covering the years 1815 to 2004, he finds that competitive oligarchies and electoral authoritarian regimes have the highest relative risk factors for democratic transitions, especially compared with plebiscitary authoritarian regimes. Notwithstanding how central the proposition of democratization by elections has become within the broader contemporary research on democratization, which is conveyed by the aforementioned scholarship, our contribution is motivated by two important weaknesses.

The first weakness that we identify is empirical. Despite the important place that region-specific analyses occupy in the literature on democratization by elections, Southeast Asian cases have been almost entirely ignored. This is surprising given that, first, most Southeast Asian countries have held multiple elections since 1945; second, most Southeast Asian regimes are not democratic; and third, a few Southeast Asian countries have experienced democratic transitions or periods of political liberalization under authoritarian rule. Often missed by nonspecialists is the fact that Southeast Asia is also a large world region. With a population of approximately 650 million people (2017), Southeast Asia is roughly equal in population to Latin America and more populous than the European Union or the Arab League. In empirical terms, then, Southeast Asia holds great promise as a laboratory for testing and refining our understanding of the role of elections in democratization. Several of the regional chapters in Lindberg (2009a), along with related literature on African politics in particular (see Lemke, 2003; Moehler \& Lindberg, 2009), have shown how a regional focus can be especially illuminating for testing and refining general theoretical propositions.

Southeast Asia as a region of analysis also has some particular benefits for comparative analysis (see Kuhonta et al., 2008). The region is internally diverse according to ethnicity, language, religion, geography, colonial experience, conflict, level of income, state capacity, and other factors. This enables cross-national comparative analysis across key factors that might explain regime trajectories. The postcolonial political experiences of Southeast Asian countries also vary considerably over time in some instances, with countries such as Cambodia, Indonesia, and Myanmar transitioning between authoritarian regime subtypes (Geddes, Wright, \& Frantz, 2014). At the same time, Malaysia and Singapore have featured institutional 
continuity for most of their independent history. For all of these reasons, within-region, cross-country comparative analyses drawing primarily and even exclusively on Southeast Asian cases occupy a central place in the recent literature on authoritarianism, democratization, and elections (Hicken, 2009; Jayasuriya \& Rodan, 2007; Morgenbesser, 2016b; Pepinsky, 2009; Sidel, 2008; Slater, 2010; Weiss, 2007).

We refer to these important works to establish that any general literature on elections or democratization must consider Southeast Asian cases to be truly general and comparative in scope (for a related argument, see Bunce, 2003). To date, however, Southeast Asian cases only appear in this literature as data points in several global regression analyses (e.g., Donno, 2013b; Edgell et al., 2015; Miller, 2015a). By focusing closely on Southeast Asia, we contribute new empirical evidence on the incidence of democratization by elections in a vital world region. We examine important cases - such as the Philippines (1986), Indonesia (1999), Cambodia (2013), and most recently Myanmar (2015) - that have heretofore escaped attention in the existing literature to examine the explanatory capacity of democratization by elections. This allows us to leverage the internal diversity of Southeast Asia as a region to contribute new conceptual and theoretical insights.

The second weakness is conceptual: The conflation of elections as causes of rather than features of democracy. We outline the conceptual challenges in the relationship between elections and democratization, and their empirical implications, in the following section.

\section{Elections and Democracy: Constitutive and Causal Relationships}

Most definitions of democracy consider elections to be the single defining feature of democratic rule. This means that the presence of a competitive election is an indicator that captures the existence of democracy, and the outcome of a dictator stepping down after a multiparty election is an indicator of democratization haven taken place. This is the position taken in work as varied as Huntington (1991) to Alvarez, Cheibub, Limongi, and Przeworski (1996). By contrast, democratization by elections holds that elections cause democracy: The existence of elections-perhaps only competitive elections or perhaps even highly restricted electionsincreases the likelihood of a democratic transition. This proposition induces a potential tautology. In the framework of democratization by elections, elections are the causes of the outcomes that elections themselves measure. Elections are both the independent and the dependent variable. 
The foundational work on democratization by elections recognized this tension. We agree with Lindberg (2009a, pp. 316-319) and other authors (Bunce \& Wolchik, 2011, pp. 15-16; Donno, 2013b, p. 708; Edgell et al., 2015 , pp. 5-6) that it is logically consistent to hold that elections increase the likelihood that a democratic transition occurs-that elections may cause democratization. To be a testable empirical claim, however, it must be the case that elections may not cause democratization. Even if elections may logically cause democracy, any empirical investigation of this relationship must be able to distinguish between causal and noncausal relationships between elections and democratization.

What would a noncausal link between elections and democratization comprise? Alvarez et al. (1996) offer a useful conceptual template. In their conceptualization of regimes, a regime "type" (democracy or something else) is fundamentally unobservable, the joint product of the strategic choices of actors within and outside of a ruling government about how to allocate power within a state. When incumbent governments hold elections, lose, and step down, then we have observed an implication of a regime being a democracy. The regime may nevertheless have been democratic prior to the holding of the election, meaning that incumbent governments were subject to electoral constraint even if an election had not allowed us to observe them responding to this constraint. In this way, changes in the constraints, opportunities, and resources available to political actors may lead to a change from nondemocratic to democratic rule that only appears as democratic upon the subsequent holding of an election.

At first glance, it may seem puzzling to hold that democratization can precede elections - that a regime can be a democracy even if it has not yet held an election. Yet, this is precisely the conceptualization that best comports with process-based theories of regime change. In the classic Transitions From Authoritarian Rule, O'Donnell and Schmitter (1986) define democratization as

the processes whereby the rules and procedures of citizenship are either applied to political institutions previously governed by other principles ... or expanded to include persons no previously enjoying such rights ... or extended to cover issues and institutions not previously subject to citizen participation. (p. 8)

Critically, they specify that "there does not seem to be any logical sequence to these processes." It follows that the elections that definitively mark a regime as a democracy need not be temporally prior to the process of democratization. Likewise, Huntington (1991) writes that 


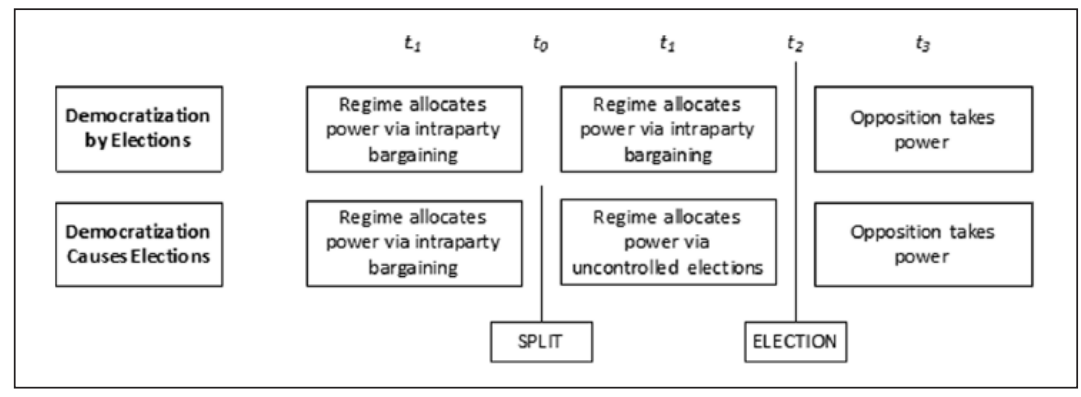

Figure I. Democratization and elections.

if popular election of the top decision makers is the essence of democracy, then the critical point in the process of democratization is the replacement of a government that was not chosen this way by one that is selected in a free, open, and fair election. The overall process of democratization before and after that election, however, is usually complex and prolonged. (p. 9)

Here, we can distinguish competitive elections and rotation of executive authority as the culmination of a process that "usually" begins prior to the election itself.

We provide a schematic representation of the relationship between elections and democratization that neatly distinguishes the causal relationship of "democratization by elections" from the constitutive relationship of "democratization causes elections" (see Figure 1). We observe a formerly authoritarian country where the opposition takes power in period $t_{3}$, following an election in $t_{2}$. In the case of democratization by elections, that election was held under a regime that allocated power in the preceding period $t_{1}$ via intraparty bargaining, and held controlled elections that it had no intention of losing.

The case of democratization causing elections requires a longer causal sequence in which the focus is on the mechanism through which authority is allocated in $t_{1}$ and previous periods. In this case, authority is allocated via uncontrolled elections in $t_{1}$ following an elite split or a comparable breakdown of the authoritarian regime in $t_{0}$. Prior to that split, in period $t_{-1}$, the regimes were identical, allocating power via intraparty bargaining. And, following the election held by both in $t_{2}$, the two countries are identifiable as democracies in $t_{3}$. But, in the case of democratization by elections, we locate the independent cause of regime change as the elections in period $t_{2}$, whereas in the case of democratization causing elections, we locate the independent cause of regime change as the elections at the elite split in period $t_{0}$ which, in 
turn, caused the election in $t_{2}$. Because the regime allocated power through uncontrolled elections in $t_{1}$, it was by definition democratic at that time, even though elections had not yet allowed that fact to be observable.

These dual pathways create problems for most indicators of democracy and cross-national statistical tests of the relationship between elections and democracy. Alvarez et al. (1996); Boix, Miller, and Rosato (2012); and other datasets on regime type use elections to measure democratization. A research strategy that selects authoritarian country-years as the analysis sample will exclude those elections that may plausibly cause democracy in that same year, because the election in year $t_{0}$ that codes the regime as a democracy $t_{0}$ appears as an election under democratic rule in the analysis sample. On the contrary, defining the analysis sample as all regimes coded as authoritarian in year $t_{-1}$ creates a mechanical relationship between elections and democratization because elections in year $t_{0}$ are by definition associated with democratization in year $t_{1}$ because they are the measures of democracy in $t_{1}$. In our cross-national statistical analysis below, we outline how we attempt to mitigate these problems. For what follows, however, the more important point is that a close qualitative investigation is essential to identify empirically the relationship between elections and democratization.

\section{Authoritarian Elections in Southeast Asia: An Overview}

To outline the empirical scope of our analysis, we list elections under authoritarian rule in Southeast Asia between 1945 and 2015 (see Table 1). Using regime classification data from Boix et al. (2012) as a starting point, we subsequently categorize elections within any given year across two dimensions - type and competitiveness. To establish the type of them, we primarily relied upon data from Coppedge et al. (2017, v2eltype) and secondarily from Nohlen, Grotz, and Hartmann (2001) as well as Hyde and Marinov (2012). To determine the competitiveness of them, we adopted the same approach as Edgell et al. (2015) and utilized data from Coppedge et al. (2017, v2elmulpar). This conceptualization accordingly focuses narrowly on the existence of multiparty elections rather than the practices that govern how realistically competitive they were. Accordingly, competitive elections are those where multiparty competition is either constrained, partially upheld, or fully practiced (scores two to four), while noncompetitive elections are those with either no parties or single-party hegemony (scores zero or one). This 5-point ordinal scale provides a nuanced account of electoral competition among Southeast Asia's authoritarian regimes. 
Table I. Elections Under Authoritarianism in Southeast Asia.

\begin{tabular}{|c|c|c|}
\hline Type & Competitive & Noncompetitive \\
\hline Legislative & 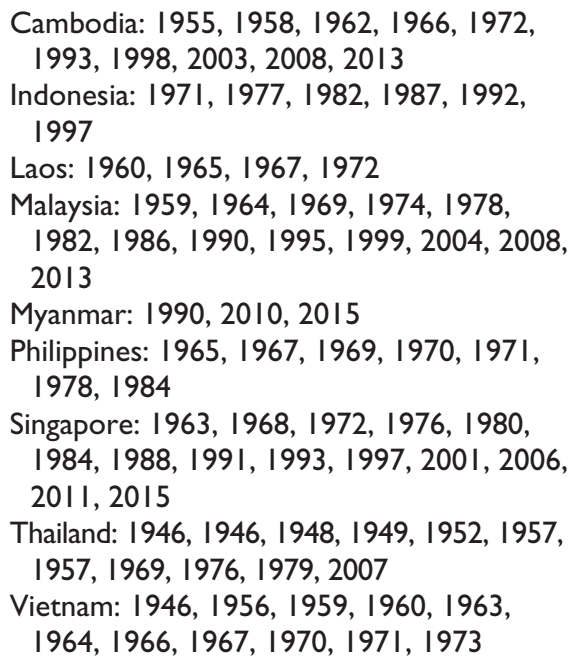 & $\begin{array}{l}\text { Cambodia: 1976, I98I } \\
\text { Laos: I989, 1992, I997, } \\
\text { 2002, 2006, 201 I } \\
\text { Myanmar: 1974, I978, } \\
\text { I98I, 1985 } \\
\text { Vietnam: 197I, 1975, } \\
\text { 1976, 198I, 1987, } \\
\text { I992, 1997, 2002, } \\
\text { 2007, 20II }\end{array}$ \\
\hline Executive & $\begin{array}{l}\text { Cambodia: } 1972 \\
\text { Philippines: 1965, 1967, 1969, 1973, 1977, } \\
\quad \text { I986 } \\
\text { Singapore: 1993, 201। } \\
\text { Vietnam: 1955, 1961, 1967, 1971 }\end{array}$ & $\begin{array}{l}\text { Philippines: I981 } \\
\text { Singapore: 1999, } 2005 \\
\text { Vietnam: I97I }\end{array}$ \\
\hline
\end{tabular}

Several observations immediately stand out about authoritarian elections in Southeast Asia. First, elections under authoritarianism are quite common in Southeast Asia, with a total of 114 elections held throughout the region over 70 years. Second, most countries in Southeast Asia have some experience with authoritarian elections, with only Brunei Darussalam (a sultanate) and Timor-Leste (never coded as an authoritarian regime) not featuring. Third, and more interestingly, most authoritarian elections in Southeast Asia are competitive elections, which count for 88 out of the 114 elections (77\%) in Table 1. This finding runs counter to any impression of elections in Southeast Asia, as wholly managed affairs with no choice whatsoever. Even though Southeast Asia's authoritarian regimes have usually strictly controlled party formation, campaigning, and electoral freedom, the majority of elections in Southeast Asia feature at least two political parties or two candidates competing for office. Indeed, most of Southeast Asia's elections are not merely "elections without choice" (Hermet, Rose, \& Rouquié, 1978); they are more complicated events involving multiple actors participating in a 
managed affair, even if the ruling party and dictator have no intention of allowing their opponents to unseat them.

Our final conclusion emerges when considering Table 1 in light of the region's experience with democracy. Put simply, elections are common in Southeast Asia, but democratization is rare. We can thus update the twodecades-old finding that "with the partial exception of the Philippines prior to Marcos's declaration of martial law in 1972, and the 1975 and 1995 parliamentary elections in Thailand, elections for presidents and legislatures have never directly caused a change in government" (Taylor, 1996, p. 3). Given 70 years of data from across the region, elections under authoritarian rule in Southeast Asia have almost never been followed by a change in government.

\section{Case Study Evidence}

We now turn to case histories of authoritarian elections in the region to examine the relationship between elections and democratization in Southeast Asia in more depth. We adopt two case selection strategies for this qualitative historical approach. The first is to examine all cases of democratization in the region, and then to trace the causal role of elections on transitions. As is well known, selecting on the dependent variable in this way does not allow us to characterize the average relationship between elections and democratization, while also risking selection bias (Geddes, 1990). However, if the causal mechanisms and/or causal sequencing attributed to elections do not fit these cases where democratic transitions have actually occurred, then this is especially problematic for the hypothesis that elections play a causal role in democratization. By selecting every case of democratization, we can examine those that ought to be predicted by existing theory to test whether, in fact, these predictions hold up to empirical scrutiny.

Our second strategy is to study those authoritarian elections that ought to be particularly propitious for democratic political change based on the existing literature on democratization by elections. By selecting "on the line" cases (Lieberman, 2005), we can investigate how those hypothesized mechanisms work in practice while avoiding selection bias. Finding that elections which are most likely to lead to democratic transitions - using existing theory but different regional evidence-do not actually transition would be evidence that a different set of initial conditions make elections causes of democratization or, alternatively, that elections only have weak explanatory power as determinants of democratic transitions within Southeast Asia. 


\section{Successful Cases: Philippines, Indonesia, and Thailand}

Our first case studies focus on instances of democratization within the region. The purpose of is to examine the role of elections in where democratization has occurred. Since 1945, three Southeast Asian countries have experienced democratic transitions: the Philippines (1986), Indonesia (1999), and Thailand (on four separate occasions). To preview our conclusions, we find that, of these six democratic transitions, only the Philippines fits well within the framework of elections as a cause of democratization.

The Philippines in 1986 is perhaps a paradigmatic instance of democratization by elections (see, for example, Schedler, 2009, p. 303). After declaring martial law in 1972, President Ferdinand Marcos presided over a period of no legislative elections, ruling through personalist means authenticated by executive elections (see Thompson, 1998). He subsequently attempted to build a new mass-based political organization known as the New Society Movement beginning in 1978. At the same time, pressures against his regime began to build. Some of these were external in nature, most notably declining foreign revenues through trade, aid, and remittances that corresponded with the worldwide economic slowdown of the 1980s. Economic hardship was compounded by increasing pressure from the United States, a critical source of foreign and military aid to the Marcos regime, in response to the excesses of corrupt and personalist rule and especially in the wake of the murder of opposition leader Benigno Aquino in 1983.

Marcos thus entered the elections of 1986 in relatively weak position. Despite being in nominal control of the instruments of state power, the decision to call snap elections in 1986 represented an attempt by a weakened Marcos to use elections to bolster his flagging fortunes. Marcos claimed victory; yet, the election was roundly condemned by Filipino and foreign observers alike as fraudulent. What emerged in the response was the socalled EDSA revolution (so named after a major thoroughfare in Manila, Epifanio de los Santos Avenue), in which millions of citizens protested against Marcos and his corrupt and authoritarian rule. Mass mobilization, combined with increased diplomatic pressure from the United States, public opposition from the Catholic Church, and continued economic crisis ultimately turned Marcos's remaining allies against him. In the end, the formerly compliant Filipino security forces, led by police chief Fidel Ramos and defense secretary Juan Ponce Enrile, turned against Marcos, forcing him into exile and marking the end of the Marcos dictatorship. What followed was the reestablishment of Philippine democracy.

The case of the Philippines illustrates nicely the role that elections can play in democratization. Although Marcos's regime faced several challenges 
prior to the events of 1986, the contested election proved critical for mobilizing opposition forces. But what is the causal role of the 1986 election itself? Note that Marcos entered the election from a position of weakness; in the words of one observer,

The underlying reality ... was that the Marcos regime had already destroyed itself . . . Nonetheless, the regime stole the election and declared itself the winner. What followed was a classic demonstration of a hollow regime's inability to deploy force against an adversary. (Overholt, 1986, pp. 1161-1162)

Subsequent analyses have downplayed the importance of protest and mobilization in the transition (Fukuoka, 2015), but even critics recognize the importance of elections in the transition process - as Thompson (1995) argues, elections combined with the Philippines's legacy of democracy help to explain why the collapse of Marcos yielded democratization rather than some other form of military, personalist, or communist rule. Counterfactually, without 1986 election as a focal point for mobilization and a clear signal to domestic and international forces of Marcos's absence of electoral support, perhaps the Philippines would have not have undergone a democratic transition in 1986. But Marcos's regime was certainly fragile. Perhaps the safest conclusion is that without the 1986 elections, had a democratic transition taken place in the Philippines in 1986 or after, it probably would have taken a different form.

The case of Indonesia in 1999 shares several important features with the Philippines, including a highly corrupt dictator and deteriorating economic conditions prior to democratization. Unlike the Philippines, however, Indonesia's New Order regime under Soeharto had presided over six elections, held first in 1971 and then at regular 5-year intervals beginning in 1977. Whereas Marcos's New Society Movement was but an embryonic attempt to institutionalize support for his regime, Indonesia's Golkar was a highly institutionalized, corporatist mass organization closely affiliated with the Indonesian bureaucracy and with institutional reach throughout the archipelago. The New Order state was by any measure stronger and more capacious than the Philippine state under Marcos (Slater, 2010, p. 8). Still other important differences include the severity of the economic crisisIndonesia's economy contracted by a stunning $13 \%$ in 1998 as a consequence of the Asian economic crisis and the attended political and economic dislocation - and the presence of mass violence, which erupted during May 1998 and again later that year.

Indonesia's 1999 elections, however, are usually considered the endpoint rather than a cause of Indonesian democratization. This is because the 
decision to permit competitive elections preceded the elections themselves. Between 1977 and 1997, the New Order only allowed three political organizations to contest elections: Golkar (not formally a political party, but rather a "mass organization"), the Indonesian Democratic Party, and the United Development Party. Golkar always won around $70 \%$ of the popular vote and occupied the majority of seats in the People's Representative Council. In 1999, no less than 48 political parties contested in Indonesia's legislative elections, and Golkar came in second with only $22 \%$ of the vote (see Ruland, 2001). Although it is impossible to identify the exact moment at which Indonesian politics became competitive, after Soeharto's resignation in May 1998, Indonesia saw the flourishing of new independent political parties. Soeharto's successor, B. J. Habibie, oversaw the drafting of new electoral laws (on this period, see Horowitz, 2012, pp. 60-70). Although Indonesia would continue to tinker with its electoral institutions for more than a decade, the legal and regulatory foundations for democratic elections were in place prior to the onset of campaigns in May 1999.

Thus, authors writing from many different perspectives implicitly mark the 1999 elections as the culmination of Indonesia's democratic transition, and locate the dynamics of democratization itself in the decisions made by economic elites (Pepinsky, 2009), mass mobilization (Aspinall, 2005), regime elites and political parties (Horowitz, 2012), and other social and political forces prior to the 1999 elections. There was some uncertainty prior to May 1999 about whether or not the conduct of elections would meet minimum standards of orderliness, but no doubt whatsoever about whether or not they would be competitive elections.

Cross-national indices of regime type that use elections as their indicator of democratization will code Indonesian democratization as having occurred in 1999. Our analysis implies that, although the coding rule has been correctly applied, it misses the correct causal process. Although some authors are aware of this kind of ambiguity (see, for example, the discussion in Alvarez et al., 1996, pp. 10-13), our analysis reveals how it may affect the inferences that analysts draw using these data.

What of the argument that authoritarian elections did foster Indonesian democratization by putting in place the institutions that would later be used by pro-democracy forces? In a narrow sense, this is plainly true; Indonesia's mass public had become habituated to conducting flawed elections over three decades, and the costs of establishing electoral institutions were accordingly lower than they would have otherwise been. Yet, we argue that to explain regime change itself rather than the conduct of elections once they occurred, elections play no independent causal role in the Indonesian case. 
The final cases of democratic transitions come from Thailand which, by the Boix et al. (2012) data, experienced democratic transitions in 1975, 1983, and 1992. (We will consider more recent events in Thailand, below, in our discussion of ongoing cases.) Thailand is distinctive among Southeast Asian countries in its political volatility, having experienced successive periods of military rule coupled with brief periods of democratic rule. Elections demarcate Thailand's 1975 transition to democracy, but the terms of these elections were spelled out previous in the 1974 constitution that followed on the 1973 uprising that ended military rule. The Thammasat massacre of 1976 spelled the end of this brief democratic experiment. Elections also demarcated Thailand's 1983 transition, but this time emerged as a consequence of constitutional maneuvering by the military and political parties. After a brief period of military rule in 1991-1992, subsequent protests, and a royal intervention, elections marked the return to democracy in 1992. From these three transition experiences, we see little evidence of elections as causes of Thai democratization. In each case, the choices of the military together with party elites and (in 1975 and 1992) mass mobilization prove instrumental in pushing for democratic reforms that culminated in elections. In fact, these cases illustrate that, for Thai military and political parties, elections are what constitute democracy itself; they are not a procedure that causes democratization.

\section{Failed Cases: Cambodia, Singapore, and Malaysia}

The overall record on democratic transitions in Southeast Asia shows that only one out of six transition experiences analyzed above can be attributed to the causal role to elections themselves. We use the remaining five cases to demonstrate how elections signify the outcome of democratic transitionsthat is, observable manifestations of changes to the political order that predate them. The focus is not on instances of democratization, but on instances of authoritarian durability via elections.

Despite representing a most-likely case for democratization by elections, Cambodia has failed to move toward democracy in any tangible way. Since 1979, the incumbent Cambodian People's Party-formally the Kampuchean People's Revolutionary Party - has sanctioned five multiparty legislative elections. A particularly salient event was the 1993 election, which was administered by the international community under the auspices of the United Nations Transitional Authority in Cambodia (UNTAC). The overarching goal was not only to separate the state from society so that legal-rational institutions could develop but also to educate citizens and political parties on the relationship between elections, democracy, and human rights through a nationwide education program. Held within an atmosphere of intimidation, mistrust, and 
violence, the 1993 election resulted in a win for the National United Front for an Independent, Peaceful, and Cooperative Cambodia (FUNCINPEC) over the ruling Cambodia People's Party (CPP). This led some CPP elites to threaten secession, which was a serious concern given that the ruling party controlled the administrative apparatus of government and retained the loyalty of sizable military and police factions. In an atmosphere of growing instability, a coalition government was eventually formed that allowed the prime ministership to be shared between FUNCINPEC's Norodom Ranariddh and the CPP's Hun Sen.

In July 1997, however, Hun Sen initiated a swift coup against Norodom Ranariddh. Subsequent elections have not only been competitive but also contain many of the mechanisms that should have enabled democratization by elections (Lindberg, 2009b, p. 329). The first is the manipulation and misconduct that has characterized all stages of the electoral cycle. During the 1993 election, which was the freest and fairest held in modern Cambodia, CPP-led violence led to approximately 176 deaths, 316 injuries, and 67 abductions (Plunkett, 1994, p. 71). Since the early 1990s, in fact, the CPP has faced a gradually more sophisticated opposition movement. At the 2013 election, for instance, a unified effort from the Sam Rainsy Party and the Human Rights Party - who allied together as the Cambodian National Rescue Party (CNRP) - produced a $10.6 \%$ swing against the ruling party. This represented the first time two opposition parties had coalesced to challenge the CPP's dominance. Opposition parties have also increasingly utilized electoral tactics that have helped topple authoritarian regimes elsewhere (Bunce \& Wolchik, 2011). These include ambitious campaigns, voter registration and turnout drives, pressures on election commissions, collaboration between civil society and youth movements, exit polls, and parallel voter tabulation (Morgenbesser, 2017). During the 2013 election, the application of this "electoral model" was evident in the way the CNRP held marches, led citizen meetings, conducted door-to-door canvasing, organized concerts, and then supervised the vote count. The final mechanism that ought to enable democratization in Cambodian elections is popular protests, which were found to be causally relevant in the Philippine case. In 1998, for example, demonstrations took place over a 3-week period after the National Election Commission dismissed opposition complaints about the election result. This led Hun Sen to declare that "if the opposition thinks I'm going to step down they're dreaming . . . and if they try to dissolve the present government by other means they will face military action" (in Grainger \& Chameau, 1998, p. 1). A similar pattern occurred following the 2013 election. When the National Election Commission again dismissed opposition complaints, the CNRP boycotted the National Assembly and demanded an investigation into electoral irregularities by an independent commission with international 
support. Over the next few months, it coordinated scores of multiday protests involving upward of 40,000 supporters in Phnom Penh alone (Quinlan, Ponniah, \& Boyle, 2013). Ultimately, popular protests represent a quintessential feature of Cambodian elections.

Because Cambodia represents an "on the line" case for democratization by elections, it is worth analyzing what explains the countervailing persistence of authoritarianism. Because France established a protectorate over Cambodia in 1863, anthropologists, historians, and political scientists have documented the pervasive influence of neopatrimonialism on its development (Hughes, 2003; Mabbett \& Chandler, 1995; Peang-Meth, 1991). Today, the CPP sits atop a sprawling system of domination that combines informal personal relationships of loyalty and dependence with formal state institutions of authority and officialdom. In a political system that has no clear purpose beyond its own perpetuation, Strangio (2014) details how

political stability [has] rested not on any deep social or political consensus, but on a tenuous pact between the country's elites, whose loyalties had to be constantly renewed through fresh distributions of profits and patronage. There [is] no goal beyond the endless branching and twining of patronage strings, no objective beyond the capturing of fresh resources to swell the system further. (p. 129)

The existence of neopatrimonialism is particularly problematic because this mode of domination has been shown to be resistant to democratization (see Bratton \& van de Walle, 1994; Brownlee, 2002; Snyder, 1992). Another countervailing force is Hun Sen's personalist dictatorship. In comparison with the other institutional arrangements of authoritarian regimes, personalist subtypes have a failure rate far lower than military subtypes, but slightly higher than party-based subtypes (Geddes et al., 2014). Since 1985, Hun Sen has assumed authority across six domains: gatekeeping of the process by which people are appointed to high office; appointment of relatives to highlevel posts in the party, military, or government; creation of a paramilitary group outside the normal chain of military command; control of the security apparatus; monopoly of the decision-making process within the party executive committee; and management of who enters and exits that committee (Morgenbesser, 2018). The onset of Hun Sen's personalist dictatorship has come at the expense of elections, which constitute a weak mechanism for democratization. The absence of a regularized method to remove personalist dictators typically encourages marginalized elites and disgruntled citizens to oust them using irregular means, such as assassination or revolution. This remains the most likely course for regime change in Cambodia. 
Singapore's People's Action Party (PAP) has overseen more competitive elections under authoritarianism than any of its regional counterparts. Since 1959, when it came to power, 14 parliamentary elections and four presidential elections have been held without any noticeable movement toward democracy (for an opposing view, see Ortmann, 2011). After obliterating the opposition Barisan Sosialis ahead the 1963 election, on the grounds its members were allegedly communist sympathizers, the PAP was able to implement an array of administrative and legal reforms that aided its subsequent domination of Singaporean politics. Beginning under Lee Kuan Yew, it curtailed civil liberties and political rights, reduced judicial independence, censored the media, undermined prospective opposition parties, and captured control of the Elections Department (see Lydgate, 2003; Rajah, 2012). Later, under Goh Chok Tong and Lee Hsien Loong, minor artificial changes were made to this system to make it more consultative and inclusive.

Singapore's lack of democratization has also persisted despite the presence of many factors theorized to be causally relevant in the context of elections. This includes the legalization of opposition and political associations, use of electoral manipulation (via gerrymandering), international criticism and pressure, increased voter awareness and mobilization, organizations and institutions vested in pro-democratic action, increased size and complexity of opposition challengers, spread of democratic ideals, and expectations and reliance on winner-take-all institutions (Lindberg, 2009b, p. 329). Such mechanisms have proven to be ineffective in the case of Singapore, where the PAP has succeeded by fusing flawed elections to a developmental state and a communitarian ethos (Barr, 2012; Chua, 1995). This status quo has been undergirded by a strong state, which has consistently provided the capacity to coerce rivals, extract revenues, register citizens, and/or cultivate dependence (see Slater, 2012; Slater \& Fenner, 2011). A critical component is the peculiar nature of Singapore's electoral system among authoritarian regimes, in which voting and vote-counting systems are free from manipulation and misconduct, but opposition parties are inhibited by unfair rules and regulations. In the end, elections are apparently free enough to confer legitimacy on the PAP (Morgenbesser, 2016a), but unfair enough to ensure its survival. Because the fate of ruling party has always been intricately linked to the fate of Singapore as an independent state, this arrangement has never been conducive to democratization by any means.

The case of Malaysia ought to be even more propitious for democratization by elections. After Singapore, no other Southeast Asian country has held more competitive authoritarian elections, a total of 13 since independence. Malaysia's elections have also been much more competitive than Singapore's. Since 1959, the first election after independence, opposition parties have held 
no less than $10 \%$ and as much as $40 \%$ of the seats in the Dewan Rakyat, Malaysia's lower house of parliament. Nearly, all of the mechanisms outlined in Lindberg (2009b, p. 329) may be found in Malaysia: legal opposition parties, electoral manipulation (also via gerrymandering and malapportionment, see Ostwald, 2013), international criticism and pressure, increased voter awareness and mobilization, organizations and institutions vested in prodemocratic action, increased size and complexity of opposition challengers, and the spread of democratic ideals. In recent decades, moreover, trends have increasingly favored the opposition, with an increasingly sophisticated electorate, a vibrant and relatively uncontrolled online media that covers the opposition evenhandedly (unlike the regime-compliant broadcast and print media), and the country's three main opposition parties formed a formal opposition coalition between 2008 and 2015.

Perhaps even more than any other country in the region, Malaysia is where elections would not just signal but actually cause a democratic transition. In the critical elections of $1969,1990,1999$, and 2013, incumbent and opposition figures have seen elections as the sites of political contestation rather than what follows after a breakdown of the incumbent regime. The so-called "electoral tsunami" of 2008, in which nonregime parties gained $37 \%$ of parliamentary seats, was so termed because it was so surprising; had the results been even stronger for the opposition, then either a transition would have ensued or parliament would have been suspended (as it was following the elections of 1969).

Why, then, have elections not (yet) led to democratization in Malaysia? There are several factors that have shielded the regime from democratizing pressure. Prime Minister Mahathir Mohamad effectively moved Malaysian politics in a more personalist direction (Hwang, 2003; Slater, 2003), allowing him to respond quickly and decisively to challenges from below. Malaysia also benefits from a strong state that allows the Barisan Nasional (BN) regime to manage elections effectively and to maintain effectively the networks of patronage that bind elites together (Slater, 2010).Together, these factors mean that when faced with acute economic shocks, the regime has proven adept at maintaining those flows of resources (Pepinsky, 2009). As a result, although elections are exactly the focal point for anti-incumbent mobilization that the literature on democratization by elections predicts, they are also opportunities for the regime to demonstrate its strength and capaciousness.

\section{Ongoing Cases: Thailand and Myanmar}

To conclude our qualitative case study approach, we consider the cases of elections in Myanmar and Thailand. Because Thailand is currently led by a 
military junta and has weathered twin coups in the past decade, it is difficult to determine whether 2008 represents an instance of meaningful democratization. The 2007 election, which presaged this transition, marked the decision of the Council for National Security, which had ousted Thaksin Shinawatra in a 2006 coup, to return to civilian rule. The 2014 coup brought this most recent iteration of democratic rule to a close. In keeping with Thailand's earlier political history, elections have emerged as a consequence of decisions among elites to return to civilian rule, rather than a cause of democratization.

Myanmar's election history warrants deeper scrutiny. It offers promising, but illusory, support for the theory of democratization by elections. After four noncompetitive elections under the Burma Socialist Program Party in the 1970s and 1980s, Myanmar has since experienced three competitive elections sanctioned by the military or a civilian-front party. The 1990 election famously resulted in a landslide victory for the opposition National League for Democracy (NLD). If there were ever an opportunity for an election to cause democratization, this would have been it, but the NLD was prevented from forming a government and the results were ignored by the military. The 2010 election, by contrast, produced a highly flawed victory for the militarybacked Union Solidarity and Development Party (USDP). Afterward, the new government embarked on a liberalization program focused on instituting substantive, but targeted, administrative, socioeconomic, and political changes (see Cheesman, Skidmore, \& Wilson, 2012). The endpoint of this reform process was the 2015 election, which the USDP under Thein Sein lost in a stunning rout to the NLD under Aung San Suu Kyi.

The long overdue transfer of power witnessed in Myanmar appears to be a case of a flawed election fostering democratization. Such a conclusion, however, ignores the predominant role of the military in national politics. Learning not only from the Indonesian model (see Sundhaussen, 1995), but also from the extrusion experiences of other military regimes, Myanmar's military established reserve domains to ensure it would exert political influence regardless of the party in government. Finer (1985) famously argued that militaries withdraw from politics once three conditions have been met: all significant elements of the armed forces concur with the decision; the individual and corporate interests of the military are protected; and there is a politically viable civilian organization for the transfer of authority. This explanation has been found to be very applicable to Myanmar (Morgenbesser, 2016b). Between 2008 and 2015, the military put in place the legal and institutional guarantees it felt it required for a partial hand-back of executive authority. In political terms, the new strategic priority was to safeguard the very constitution that safeguards the military. Among many contentious 
provisions, it reserves $25 \%$ of the seats in parliament for the military (giving it an effective veto on constitutional amendments); stipulates that the president must be acquainted with the military; gives the military the power to elect one of the three vice presidents; and leaves space for the military-dominated National Defence and Security Council to assume sovereign powers. Against this backdrop, the commander-in-chief of the defense services, General Min Aung Hlaing, could therefore hand back executive authority and "not be concerned" about whether the NLD took over the reins of government (in Igarashi, 2015). The same level of certainty was conveyed by Thein Sein (2015), who twice acknowledged that the election would produce nothing short of a "new political arrangement" for the country.

Myanmar's widely lauded 2015 election represented a mechanism to safeguard military prerogatives on terms set by the military, rather than an independent cause of democratization. Although the 1990 election result had threatened the military with the prospect of sudden and unprotected adaptation, but the 2015 election result offered it incremental and protected adaptation (see Maung Aung Myoe, 2014; Taylor, 2015). A close analysis of the dynamics of military politics and regime change, especially between 2010 and 2015, casts doubt on the premise that the election played an independent causal role in Myanmar's transition. If democratization has occurred, the historic election constituted the culmination of an established process.

\section{Democratization by Elections: Regional Versus Global Patterns}

Our analysis so far has provided little evidence that elections cause democratization within Southeast Asia. To review our findings, when looking at all instances of democratization, only the Philippines (1986) is consistent with an argument that elections can cause democratization. When looking at those elections that ought to be most propitious for democratic transitions, we find that dictators and ruling parties have fared well in resisting pressures for regime change. However, our two complementary case selection strategies may actually fail to capture aggregate patterns across the region. So, in this section, we adopt a quantitative approach and test the relationship between elections and democratization using cross-national statistical methods.

Our task is to estimate whether elections under authoritarianism increase the subsequent likelihood of democratization. We do so by taking all authoritarian country-years in Southeast Asia (as coded by Boix et al., 2012) and estimating whether an election in year $t$ (as displayed in Table 1) is correlated with a democratic transition in year $t+1$. In every model that we estimate, we include fixed effects by country and year to capture unobserved 
country-specific heterogeneity and unobserved common shocks across years (with ordinary least squares [OLS] being used as our baseline estimator). Our preferred specification is, therefore,

$$
\operatorname{DemTrans}_{i t+5}=\alpha_{i t}+\beta \text { Elections }_{i t}+\gamma \mathbf{X}_{i t}+\delta_{i}+\theta_{t}+\varepsilon_{i t},
$$

where $\beta$ is our main parameter of interest and $\mathbf{X}$ is a vector of time-varying controls that will appear in some models. Our empirical is equivalent to differences-in-differences framework, and although we will not interpret these findings as estimates of the causal effect of elections on democratic transitions, they are nevertheless useful for illustrating whether or not there is even a predictive relationship between elections and democratization within Southeast Asia.

Before proceeding, we highlight two additional issues. One is that the relationship between elections and democratic transitions may take time to appear. If so, the 1-year lead of our democratic transitions variable may not reflect the medium-term effects of elections. So, we also estimate a series of models where the dependent variable is DemTrans ${ }_{i t+5}$. Note, however, that although these models will capture more postelection democratic transitions if these transitions tend to be durable, they will tend to miss democratic transitions if the subsequent regimes tend to be fragile (as in Thailand).

A second issue reflects once again the problem of distinguishing empirically between elections as causes and definitions of democracy. As we argued above, defining the sample as all countries that are authoritarian in $t_{0}$ may mask the democratization power of elections, whereas defining the sample as all countries that are authoritarian in $t_{-1}$ creates a mechanical statistical association between elections and democratization. We confront this challenge by estimating all models both ways, taking care to consider the evidence from all of the models, cognizant of how statistical correlations may be misleading. Note that we have not attempted to recode the dependent variable of democratization, because our goal is to hew closely to existing best practices in the study of democratization by elections.

We present our baseline results with no covariates in Table 2. We find no statistically significant relationship between elections and democratization in Southeast Asia, either in the short or in the long term, using either the sample of country-years that are authoritarian in $t_{0}$ or those authoritarian in $t_{-1}$.

These quantitative results are thus consistent with our qualitative analysis. Net of unobservable country and year effects, authoritarian elections do not predict democratic transitions in Southeast Asia.

There are a number of ways to extend this analysis. In the supplemental appendix, we estimate different statistical models using the same data, include 
Table 2. Elections and Democratic Transitions in Southeast Asia.

\begin{tabular}{|c|c|c|c|c|}
\hline \multirow{2}{*}{$\begin{array}{l}\text { Dependent } \\
\text { variable }\end{array}$} & (I) & (2) & (3) & (4) \\
\hline & DemTrans $_{t+1}$ & DemTrans $_{t+5}$ & DemTrans $_{t+1}$ & DemTrans $_{t+5}$ \\
\hline \multirow[t]{2}{*}{ Election $_{t}$} & -0.02 & -0.00 & -0.02 & 0.01 \\
\hline & $(0.01)$ & $(0.01)$ & $(0.02)$ & $(0.01)$ \\
\hline $\begin{array}{l}\text { Country fixed } \\
\text { effects }\end{array}$ & Yes & Yes & Yes & Yes \\
\hline Year fixed effects & Yes & Yes & Yes & Yes \\
\hline Sample & Auth. in $t_{0}$ & Auth. in $t_{0}$ & Auth. in $t_{-1}$ & Auth. in $t_{-1}$ \\
\hline$n$ & 452 & $4 I I$ & 441 & 402 \\
\hline
\end{tabular}

Standard errors, clustered by country, in parentheses. Auth. = authoritarian. $* p<.05$. ** $p<.01$. *** $p<.001$.

models with common control variables, fixed effects logistic models, and models that distinguish between competitive and uncompetitive elections, which we code using Table 1 and alternatively by whether or not the Database of Political Institutions (Beck, Clarke, Groff, Keefer, \& Walsh, 2001) records an opposition party holding at least one seat in parliament. Our results do not change under any of these additional models. We also replace our comprehensive coding of elections in Table 1 with two general cross-national datasets on elections: NELDA (Hyde \& Marinov, 2012) and V-DEM (Coppedge et al., 2017). Again, our findings remain unchanged.

We also investigate different dependent variables using the same model as above. We include those results in Table 3. We first consider the (Cheibub, Gandhi, \& Vreeland, 2010) dichotomous regime coding. Then, we turn to the standard Polity and Freedom House data-in these models, we continue to use Boix et al. (2012) to define the analysis sample, and then control for the baseline Polity or Freedom House score at the year of the election. These models test what might be considered a more sympathetic interpretation of democratization by elections producing not a regime change but, more narrowly, political liberalization. Finally, we use the Freedom House coding of electoral democracies, exploiting the fact that, uniquely, among our dichotomous measures of democracy, they do not include political turnover as an indicator of democracy (see also Donno, 2013b, p. 708).

Our results do not change using these alternative indicators of political regime. Once again, authoritarian elections do not predict democratic transitions or political liberalization in Southeast Asia. 
Table 3. Alternative Dependent Variables.

Panel A: Cheibub, Gandhi, and Vreeland (2010) regime coding

\begin{tabular}{|c|c|c|c|c|}
\hline & (I) & (2) & (3) & (4) \\
\hline Dependent variable & DemTrans $_{t+1}$ & DemTrans $_{t+5}$ & DemTrans $_{t+1}$ & DemTrans $_{t+5}$ \\
\hline Election $_{t}$ & $\begin{array}{l}-0.01 \\
(0.01)\end{array}$ & $\begin{array}{c}0.00 \\
(0.01)\end{array}$ & $\begin{array}{c}0.01 \\
(0.02)\end{array}$ & $\begin{array}{c}0.01 \\
(0.01)\end{array}$ \\
\hline Country fixed effects & Yes & Yes & Yes & Yes \\
\hline Year fixed effects & Yes & Yes & Yes & Yes \\
\hline $\begin{array}{l}\text { Sample } \\
n\end{array}$ & $\begin{array}{c}\text { Auth. in } t_{0} \\
396\end{array}$ & $\begin{array}{c}\text { Auth. in } t_{0} \\
365\end{array}$ & $\begin{array}{c}\text { Auth. in } t_{-1} \\
\quad 387\end{array}$ & $\begin{array}{c}\text { Auth. in } t_{-1} \\
358\end{array}$ \\
\hline
\end{tabular}

Panel B: Polity2 combined score

\begin{tabular}{|c|c|c|c|c|}
\hline & (I) & (2) & (3) & (4) \\
\hline Dependent variable & Polity $_{t+1}$ & Polity $_{t+5}$ & Polity $_{t+1}$ & Polity $_{t+5}$ \\
\hline Election $_{t}$ & $\begin{array}{c}-0.21 \\
(0.18)\end{array}$ & $\begin{array}{l}-0.11 \\
(0.39)\end{array}$ & $\begin{array}{c}-0.19 \\
(0.17)\end{array}$ & $\begin{array}{l}-0.14 \\
(0.35)\end{array}$ \\
\hline Polity $_{t}$ & $\begin{array}{l}0.88^{* * * *} \\
(0.03)\end{array}$ & $\begin{array}{l}0.48^{* * *} \\
(0.12)\end{array}$ & $\begin{array}{l}0.89 * * * * \\
(0.04)\end{array}$ & $\begin{array}{l}0.51^{\text {*** }} \\
(0.12)\end{array}$ \\
\hline Country fixed effects & Yes & Yes & Yes & Yes \\
\hline Year fixed effects & Yes & Yes & Yes & Yes \\
\hline $\begin{array}{l}\text { Sample } \\
n\end{array}$ & $\begin{array}{c}\text { Auth. in } t_{0} \\
416\end{array}$ & $\begin{array}{c}\text { Auth. in } t_{0} \\
400\end{array}$ & $\begin{array}{c}\text { Auth. in } t_{-1} \\
413\end{array}$ & $\begin{array}{c}\text { Auth. in } t_{-1} \\
391\end{array}$ \\
\hline
\end{tabular}

Panel C: Freedom house, political rights

\begin{tabular}{|c|c|c|c|c|}
\hline & (I) & (2) & (3) & (4) \\
\hline Dependent variable & PolRights $_{t+1}$ & PolRights $_{t+5}$ & PolRights $_{t+1}$ & PolRights $_{t^{+}+}$ \\
\hline Election $_{t}$ & $\begin{array}{c}-0.04 \\
(0.05)\end{array}$ & $\begin{array}{l}-0.03 \\
(0.07)\end{array}$ & $\begin{array}{c}-0.08 \\
(0.05)\end{array}$ & $\begin{array}{c}-0.01 \\
(0.06)\end{array}$ \\
\hline PolRights $_{t}$ & $\begin{array}{l}0.77 * * * \\
(0.03)\end{array}$ & $\begin{array}{c}0.12 \\
(0.13)\end{array}$ & $\begin{array}{l}0.70^{* * * * *} \\
(0.09)\end{array}$ & $\begin{array}{c}0.23 \\
(0.12)\end{array}$ \\
\hline Country fixed effects & Yes & Yes & Yes & Yes \\
\hline Year fixed effects & Yes & Yes & Yes & Yes \\
\hline $\begin{array}{l}\text { Sample } \\
n\end{array}$ & $\begin{array}{c}\text { Auth. in } t_{0} \\
300\end{array}$ & $\begin{array}{c}\text { Auth. in } t_{0} \\
294\end{array}$ & $\begin{array}{c}\text { Auth. in } t_{-1} \\
308\end{array}$ & $\begin{array}{c}\text { Auth. in } t_{-1} \\
295\end{array}$ \\
\hline
\end{tabular}


Table 3. (continued)

Panel D: Freedom house, civil liberties

\begin{tabular}{|c|c|c|c|c|}
\hline & (I) & (2) & (3) & (4) \\
\hline Dependent variable & CivLib $_{t+1}$ & CivLib $_{t+5}$ & CivLib $_{t+1}$ & CivLib $_{t+5}$ \\
\hline \multirow{2}{*}{ Election $_{t}$} & 0.00 & -0.06 & 0.01 & -0.03 \\
\hline & $(0.04)$ & $(0.08)$ & $(0.03)$ & $(0.09)$ \\
\hline \multirow[t]{2}{*}{ CivLib $_{t}$} & $0.80 * * *$ & $0.34 * *$ & $0.78 * * *$ & $0.34 * *$ \\
\hline & $(0.06)$ & $(0.09)$ & $(0.07)$ & $(0.08)$ \\
\hline Country fixed effects & Yes & Yes & Yes & Yes \\
\hline Year fixed effects & Yes & Yes & Yes & Yes \\
\hline Sample & Auth. in $t_{0}$ & Auth. in $t_{0}$ & Auth. in $t_{-1}$ & Auth. in $t_{-1}$ \\
\hline$n$ & 300 & 294 & 308 & 295 \\
\hline
\end{tabular}

Panel E: Freedom house electoral democracies

\begin{tabular}{|c|c|c|c|c|}
\hline & (I) & $(2)$ & (3) & (4) \\
\hline Dependent variable & DemTrans $_{t+1}$ & DemTrans $_{t+5}$ & DemTrans $_{t+1}$ & DemTrans $_{t+5}$ \\
\hline \multirow{2}{*}{ Election $_{t}$} & -0.01 & 0.02 & -0.04 & 0.01 \\
\hline & $(0.01)$ & $(0.02)$ & $(0.04)$ & $(0.01)$ \\
\hline Country fixed effects & Yes & Yes & Yes & Yes \\
\hline Year fixed effects & Yes & Yes & Yes & Yes \\
\hline Sample & Auth. in $t_{0}$ & Auth. in $t_{0}$ & Auth. in $t_{-1}$ & Auth. in $t_{-1}$ \\
\hline$n$ & 202 & 173 & 195 & 166 \\
\hline
\end{tabular}

Standard errors, clustered by country, in parentheses. Auth. = authoritarian.

$*_{p}<.05$. **p $<.01$. ***p $<.001$.

How should we reconcile these within-region findings with the global statistical findings on democratization by elections in Donno (2013b), Edgell et al. (2015), and related research? One possibility is that within-region findings suffer from small sample size, which increases the likelihood of Type 2 error. In Table 4, we confirm our findings with regressions based on elections from the NELDA dataset (Hyde \& Marinov, 2012). When we expand our analysis by reestimating the equation in Table 2 for all authoritarian regimes around the world, we do recover a statistically significant relationship between elections and democratization.

However, even these results only obtain for the sample of authoritarian regimes the year prior to the holding an election which, as we have argued, risks confusing elections as definitions of, rather than causes of, democracy. 
Table 4. Elections and Democratization Around the World.

\begin{tabular}{|c|c|c|c|c|}
\hline & (I) & (2) & (3) & (4) \\
\hline Dependent variable & DemTrans $_{t+1}$ & DemTrans $_{t+5}$ & DemTrans $_{t+1}$ & DemTrans $_{t+5}$ \\
\hline Election $_{t}$ & $\begin{array}{l}0.01 \\
(0.01)\end{array}$ & $\begin{array}{l}-0.01 \\
(0.01)\end{array}$ & $\begin{array}{l}0.06 * * * \\
(0.01)\end{array}$ & $\begin{array}{l}0.03 * * \\
(0.01)\end{array}$ \\
\hline $\begin{array}{l}\text { Country fixed } \\
\text { effects }\end{array}$ & Yes & Yes & Yes & Yes \\
\hline Year fixed effects & Yes & Yes & Yes & Yes \\
\hline $\begin{array}{l}\text { Sample } \\
n\end{array}$ & $\begin{array}{c}\text { Auth. in } t_{0} \\
5,168\end{array}$ & $\begin{array}{c}\text { Auth. in } t_{0} \\
4,821\end{array}$ & $\begin{array}{c}\text { Auth. in } t_{-1} \\
5,08 \mathrm{I}\end{array}$ & $\begin{array}{c}\text { Auth. in } t_{-1} \\
4,732\end{array}$ \\
\hline
\end{tabular}

Standard errors, clustered by country, in parentheses. Auth. = authoritarian. $* p<.05 . * * p<.01$. *** $p<.001$.

A second possibility is that factors specific to the Southeast Asian region, or common among Southeast Asian countries, explain this regional anomaly. We speculate that there are several causal pathways operating in Southeast Asia that allow the region's authoritarian regimes to hold authoritarian elections repeatedly while only rarely succumbing to democratic transitions. In a companion article (Morgenbesser \& Pepinsky, 2017), we identify and explain how common features of Southeast Asian regimes - state capacity and effective neopatrimonialism - shape long-term political and institutional trajectories in this region.

\section{Conclusion}

This article has brought Southeast Asian cases into conversation with the literature on democratization by elections. Despite a long history of competitive multiparty and multicandidate elections under authoritarian rule, the vast majority do not augur democratization. By combining case studies of Cambodia, Indonesia, Malaysia, Myanmar, Philippines, Singapore, and Thailand with a statistical analysis of the relationship between elections and democratization, we have illustrated the limits of democratization by elections as an explanatory framework across this important world region. We see instead that elections generally represent the fulfillment of protracted process of regime change instigated by softliners within the regime in negotiation with civil society actors and movement entrepreneurs. Where elections actually do generate surprising results from the perspective of authoritarian regimes, such as Myanmar in 1990 and Malaysia in 1969, they 
typically respond by cracking down on the opposition and retooling the arsenal of repression.

The Philippines in 1986 is the sole exception within the region. We can conclude from this case that, indeed, elections can have causal effects on democracy - consistent with existing work. But our more general conclusion is that without careful attention to the causal processes and constitutive relations that link elections and democracy, we will overstate the generality of this causal effect, especially in quantitative research.

Our analysis also highlights the importance of Southeast Asia to the study of comparative politics. Despite sometimes being the subject of neglect by the wider field, the region has always been known by Southeast Asianists to offer fertile ground for developing and testing concepts and theories. This is because its extraordinary cultural, historical, and political variation provides a means to challenge, reformulate, and build theoretical propositions (Kuhonta et al., 2008). Many of the traditional theories of democratization, for example, have fared poorly in Southeast Asia (Bertrand, 2013; Emmerson, 1995). Beyond Indonesia and the Philippines, authoritarian regimes in the region have long defied the hypothesis posited by the elite bargaining, institutional, structural, and historical sociological models. Updating these concerns, we have shown that democratization by elections does not adequately capture the distinct experience of Southeast Asia. This is especially concerning given the enduring abundance of authoritarian regimes and the frequency by which they have sanctioned competitive, but flawed, elections.

Future work can extend our analysis both theoretically and empirically. Theoretically, scholars of the democratizing power of elections might investigate the conditions under which regime elites strategically appeal to elections that they know that they will probably lose to "win" a larger political game. In this way, the literature on elite settlements (Burton \& Higley, 1987; Higley \& Burton, 1989) should be a useful starting point. Under what conditions do elections truly "surprise" elites, and under what conditions do elites anticipate what will happen to them, and nevertheless choose elections to manage political change mostly on their own terms? This fits an emerging body of research on the varying trajectories of authoritarian regimes posttransition (Escriba-Folch, 2013; Geddes et al., 2014; Wright \& Escribà-Folch, 2012). Our analysis underscores the primacy of elections as a noncoercive endpoint of regime change, whereby political elites - especially those originating from single-party subtypes - are able to preserve a modicum of power for themselves in new democracies. This is what occurred in Indonesia, Myanmar, and Thailand. Beyond Southeast Asia, a natural empirical extension of our analysis would be to look at other world regions and investigate how processes of regime change interact with competitive elections. This 
would contribute to a general understand of the conditions under which authoritarian elections are independent causes of democratization.

\section{Authors' Note}

The authors are responsible for all errors.

\section{Acknowledgments}

The authors thank Staffan Lindberg, Anna Lührmann, Mike Miller, Jason Sharman, Dan Slater, the editors of Comparative Political Studies, and seminar participants at the Institut Barcelona d'Estudis Internacionals (IBEI), University of Minnesota, and University of Texas for helpful comments on earlier drafts.

\section{Declaration of Conflicting Interests}

The authors declared no potential conflicts of interest with respect to the research, authorship, and/or publication of this article.

\section{Funding}

The authors received no financial support for the research, authorship, and/or publication of this article.

\section{ORCID iD}

Thomas Pepinsky (iD) https://orcid.org/0000-0002-4000-217X

\section{References}

Alvarez, M., Cheibub, J., Limongi, F., \& Przeworski, A. (1996). Classifying political regimes. Studies in Comparative International Development, 31, 3-36.

Aspinall, E. (2005). Opposing Suharto: Compromise, resistance, and regime change in Indonesia. Stanford, CA: Stanford University Press.

Barr, M. (2012). The bonsai under the banyan tree: Democracy and democratisation in Singapore. Democratization, 21, 29-48.

Beaulieu, E. (2014). Electoral protest and democracy in the developing world. New York, NY: Cambridge University Press.

Beck, T., Clarke, G., Groff, A., Keefer, P., \& Walsh, P. (2001). New tools in comparative political economy: The database of political institutions. World Bank Economic Review, 15, 165-176.

Bertrand, J. (2013). Political change in Southeast Asia. New York, NY: Cambridge University Press.

Boix, C., Miller, M., \& Rosato, S. (2012). A complete data set of political regimes, 1800-2007. Comparative Political Studies, 46, 1523-1554.

Brancati, D. (2016). Democracy protests: Origins, features, and significance. New York, NY: Cambridge University Press. 
Bratton, M., \& van de Walle, N. (1994). Neopatrimonial regimes and political transitions in Africa. World Politics, 46, 453-489.

Bratton, M., van de \& Walle, N. (1997). Democratic experiments in Africa: Regime transitions in comparative perspective. New York, NY: Cambridge University Press.

Brownlee, J. (2002). And yet they persist: Explaining survival and transition in neopatrimonial regimes. Studies in Comparative International Development, 37, 35-63.

Brownlee, J. (2009). Portents of pluralism: How hybrid regimes affect democratic transitions. American Journal of Political Science, 53, 515-532.

Bunce, V. (2003). Rethinking recent democratization: Lessons from the post communist experience. World Politics, 55, 167-192.

Bunce, V., \& Wolchik, S. (2010). Defeating dictators: Electoral change and stability in competitive authoritarian regimes. World Politics, 62, 43-86.

Bunce, V., \& Wolchik, S. (2011). Defeating authoritarian leaders in postcommunist countries. Cambridge, UK: Cambridge University Press.

Burton, M. G., \& Higley, J. (1987). Elite settlements. American Sociological Review, 52, 295-307.

Cheesman, N., Skidmore, M., \& Wilson, T. (Eds.). (2012). Myanmar's transition: Openings, obstacles and opportunities. Singapore: Institute of Southeast Asian Studies.

Cheibub, J., Gandhi, J., \& Vreeland, J. (2010). Democracy and dictatorship revisited. Public Choice, 143, 67-101.

Chua, B. (1995). Communitarian ideology and democracy in Singapore. London, England: Routledge.

Coppedge, M., Gerring, J., Lindberg, S., Skaaning, S., Teorell, J., Altman, D., . . . Wilson, S. (2017). "V-Dem [Country-Year/Country-Date] Dataset v7": Varieties of Democracy (V-Dem) Project. Retrieved from at https://www.v-dem.net/en/data/dataversion-7-1/ (accessed 12 February 2018).

Dahl, R. (1971). Polyarchy: Participation and opposition. New Haven, CT: Yale University Press.

Donno, D. (2013a). Defending democratic norms: International actors and the politics of electoral misconduct. New York, NY: Oxford University Press.

Donno, D. (2013b). Elections and democratization in authoritarian regimes. American Journal of Political Science, 57, 703-716.

Edgell, A., Mechkova, V., Altman, D., Bernhard, M., \& Lindberg, S. (2015). When and where do elections matter? A global test of the democratization by elections hypothesis, 1900-2012. V-Dem Working Paper 2015:8. Retrieved from SSRN: https://ssrn.com/abstract=2638285 or http://dx.doi.org/10.2139/ssrn.2638285 (accessed 12 February 2018).

Emmerson, D. (1995). Region and recalcitrance: Rethinking democracy through Southeast Asia. The Pacific Review, 8, 223-248.

Escriba-Folch, A. (2013). Accountable for what? Regime types, performance, and the fate of outgoing dictators. Democratization, 20, 160-185.

Finer, S. (1985). The retreat to the barracks: Notes on the practice and the theory of military withdrawal from the seats of power. Third World Quarterly, 7, 16-30. 
Fukuoka, Y. (2015). Who brought down the dictator? A critical reassessment of socalled "people power" revolutions in the Philippines and Indonesia. The Pacific Review, 28, 411-433.

Gandhi, J. (2015). Elections and political regimes. Government and Opposition, 50, 446-468.

Geddes, B. (1990). How the cases you choose affect the answers you get: Selection bias in comparative politics. Political Analysis, 2, 131-150.

Geddes, B., Wright, J., \& Frantz, E. (2014). Autocratic breakdown and regime transitions: A new data set. Perspectives on Politics, 12, 313-331.

Grainger, M., \& Chameau, C. (1998, September 12-17). Demonstrations spread through capital. Phnom Penh Post, p. 1.

Hermet, G., Rose, R., \& Rouquié, A. (Eds.). (1978). Elections without choice. New York, NY: John Wiley.

Hicken, A. (2009). Building party systems in developing democracies. New York, NY: Cambridge University Press.

Higley, J., \& Burton, M. G. (1989). The elite variable in democratic transitions and breakdowns. American Sociological Review, 54, 17-32.

Horowitz, D. L. (2012). Constitutional change and democracy in Indonesia. New York, NY: Cambridge University Press.

Howard, M., \& Roessler, P. (2006). Liberalizing electoral outcomes in competitive authoritarian regimes. American Journal of Political Science, 50, 365-381.

Hughes, C. (2003). The political economy of Cambodia's transition, 1991-2001. London, England: Routledge.

Huntington, S. P. (1991). The third wave: Democratization in the late twentieth century. Normal: University of Oklahoma Press.

Hwang, I.-W. (2003). Personalized politics: The Malaysian state under Mahathir. Singapore: Institute of Southeast Asian Studies.

Hyde, S. (2011). The pseudo-democrat's dilemma: Why election observation became an international norm. Ithaca, NY: Cornell University Press.

Hyde, S., \& Marinov, N. (2012). Which elections can be lost? Political Analysis, 20, 191-210.

Igarashi, M. (2015, August 22). Myanmar army chief vows to "accept" election result. The Asahi Shimbun. Retrieved from https://web.archive.org/ web/20150823140202/ajw.asahi.com/article/asia/around asia/AJ201508220037

Jayasuriya, K., \& Rodan, G. (2007). Beyond hybrid regimes: More participation, less contestation in Southeast Asia. Democratization, 14, 773-794.

Kelley, J. (2012). Monitoring democracy: When international election observation works and why it often fails. Princeton, NJ: Princeton University Press.

Knutsen, C., Nygård, H., \& Wig, T. (2017). Autocratic elections: Stabilizing tool or force for change? World Politics, 69, 98-143.

Kuhonta, E., Slater, D., \& Vu, T. (Eds.). (2008). Southeast Asia in political science: Theory, region, and qualitative analysis. Stanford, CA: Stanford University Press.

Lemke, D. (2003). African lessons for international relations research. World Politics, $56,114-138$. 
Levitsky, S., \& Way, L. (2010). Competitive authoritarianism: Hybrid regimes after the cold war. New York, NY: Cambridge University Press.

Lieberman, E. S. (2005). Nested analysis as a mixed-method strategy for comparative research. American Political Science Review, 99, 435-452.

Lindberg, S. (2006). Democracy and elections in Africa. Baltimore, MD: Johns Hopkins University Press.

Lindberg, S. (Ed). (2009a). Democratization by elections: A new mode of transition. Baltimore, MD: Johns Hopkins University Press.

Lindberg, S. (2009b). A theory of elections as a mode of transition. In S. Lindberg (Ed.), Democratization by elections: A new mode of transition (pp. 314-342). Baltimore, MD: Johns Hopkins University Press.

Lydgate, C. (2003). Lee's law: How Singapore crushes dissent. Melbourne, Australia: Scribe.

Mabbett, I., \& Chandler, D. (1995). The Khmers. Bangkok, Thailand: Silkworm Books.

Maung Aung Myoe. (2014). The soldier and the state: The Tatmadaw and political liberalization in Myanmar since 2011. South East Asia Research, 22, 1-17.

Miller, M. (2015a). Democratic pieces: Autocratic elections and democratic development since 1815. British Journal of Political Science, 45, 501-530.

Miller, M. (2015b). Elections, information, and policy responsiveness in autocratic regimes. Comparative Political Studies, 48, 691-727.

Moehler, D., \& Lindberg, S. (2009). Narrowing the legitimacy gap: Turnovers as a cause of democratic consolidation. Journal of Politics, 71, 1448-1466.

Morgenbesser, L. (2016a). The autocratic mandate: Elections, legitimacy and regime stability in Singapore. The Pacific Review, 30, 205-231.

Morgenbesser, L. (2016b). Behind the Façade: Elections under authoritarianism in Southeast Asia. Albany: State University of New York Press.

Morgenbesser, L. (2017). The failure of democratisation by elections in Cambodia. Contemporary Politics, 23, 135-155.

Morgenbesser, L. (2018). Misclassification on the Mekong: The Origins of Hun Sen's personalist dictatorship. Democratization, 25, 191-208.

Morgenbesser, L., \& Pepinsky, T. (2017). States, neopatrimonialism, and elections: Democratization in Southeast Asia. Unpublished manuscript.

Nohlen, D., Grotz, F., \& Hartmann, C. (Eds.). (2001). Elections in Asia and the Pacific (a data handbook): Volume 2, Southeast Asia, East Asia, and the South Pacific. New York, NY: Oxford University Press.

O'Donnell, G., \& Schmitter, P. C. (1986). Transitions from authoritarian rule: Tentative conclusions about uncertain democracies. Baltimore, MD: Johns Hopkins University Press.

Ortmann, S. (2011). Singapore: Authoritarian, but newly competitive. Journal of Democracy, 22, 153-164.

Ostwald, K. (2013). How to win a lost election: Malapportionment and Malaysia's 2013 general election. The Round Table, 102, 521-532.

Overholt, W. (1986). The rise and fall of Ferdinand Marcos. Asian Survey, 26, 1137-1163. 
Peang-Meth, A. (1991). Understanding the Khmer: Sociological-cultural observations. Asian Survey, 31, 442-455.

Pepinsky, T. (2009). Economic crises and the breakdown of authoritarian regimes: Indonesia and Malaysia in comparative perspective. New York, NY: Cambridge University Press.

Plunkett, M. (1994). The establishment of the rule of law in post-conflict peacekeeping. In H. Smith (Ed.), International peacekeeping: Building on the Cambodia experience (pp. 65-78). Canberra: Australian Defence Studies Centre.

Quinlan, D., Ponniah, K., \& Boyle, D. (2013, September 15). Tens of thousands take to streets. Phnom Penh Post, p. 1.

Rajah, J. (2012). Authoritarian rule of law: Legislation, discourse and legitimacy in Singapore. New York, NY: Cambridge University Press.

Ruland, J. (2001). Indonesia. In D. Nohlen, F. Grotz, \& C. Hartmann (Eds.), Elections in Asia and the Pacific (a data handbook): Volume 2, Southeast Asia, East Asia, and the South Pacific (pp. 82-102). New York, NY: Oxford University Press.

Schedler, A. (2002). The nested game of democratization by elections. International Political Science Review, 23, 103-122.

Schedler, A. (2009). The contingent power of authoritarian elections. In S. Lindberg (Ed), Democratization by elections: A new mode of transition (pp. 291-313). Baltimore, MD: Johns Hopkins University Press.

Schedler, A. (2013). The politics of uncertainty: Sustaining and subverting electoral authoritarianism. New York, NY: Oxford University Press.

Sidel, J. (2008). Social origins of dictatorship and democracy revisited: Colonial state and Chinese immigrant in the making of modern Southeast Asia. Comparative Politics, 40, 127-147.

Slater, D. (2003). Iron cage in an iron fist: Authoritarian institutions and the personalization of power in Malaysia. Comparative Politics, 36, 81-101.

Slater, D. (2010). Ordering power: Contentious politics and authoritarian Leviathans in Southeast Asia. New York, NY: Cambridge University Press.

Slater, D. (2012). Strong-state democratization in Malaysia and Singapore. Journal of Democracy, 23, 19-33.

Slater, D., \& Fenner, S. (2011). State power and staying power: Infrastructural mechanisms and authoritarian durability. Journal of International Affairs, 65, 15-29.

Snyder, R. (1992). Explaining transitions from neopatrimonial dictatorships. Comparative Politics, 24, 379-399.

Snyder, R., \& Mahoney, J. (1999). The missing variable: Institutions and the study of regime change. Comparative Politics, 32, 103-122.

Strangio, S. (2014). Hun Sen's Cambodia. New Haven, CT: Yale University Press.

Sundhaussen, U. (1995). Indonesia's new order: A model for Myanmar. Asian Survey, $35,768-780$.

Taylor, R. (1996). Introduction: Elections and politics in Southeast Asia. In R. H. Taylor (Ed.), The politics of elections in Southeast Asia (pp. 1-11). New York, NY: Woodrow Wilson Center Press. 
Taylor, R. (2015). The armed forces in Myanmar politics: A terminating role? Singapore: Institute of Southeast Asian Studies.

Thein Sein, U. (2015, November 7). Elections will be free and fair, and truly reflect wishes of the people. Retrieved from http://www.globalnewlightofmyanmar.com/ elections-will-be-free-and-fair-and-truly-reflect-wishes-of-the-people/

Thompson, M. (1995). The anti-Marcos struggle: Personalistic rule and democratic transition in the Philippines. New Haven, CT: Yale University Press.

Thompson, M. (1998). The Marcos regime in the Philippines. In H. Chehabi \& J. Linz (Eds.), Sultanistic regimes (pp. 206-230). Baltimore, MD: Johns Hopkins University Press.

Tsebelis, G. (1990). Nested games: Rational choice in comparative politics. Berkeley: University of California Press.

van de Walle, N. (2006). Tipping games: When do opposition parties coalesce. In A. Schedler (Ed.), Electoral authoritarianism: The dynamics of unfree competition (pp. 77-92). Boulder, CO: Lynne Rienner.

Wahman, M. (2013). Opposition coalitions and democratization by election. Government and Opposition, 48, 3-32.

Weiss, M. (2007). What a little democracy can do: Comparing trajectories of reform in Malaysia and Indonesia. Democratization, 14, 26-43.

Wright, J., \& Escribà-Folch, A. (2012). Authoritarian institutions and regime survival: Transitions to democracy and subsequent autocracy. British Journal of Political Science, 42, 283-309.

\section{Author Biographies}

Lee Morgenbesser is a lecturer with the School of Government and International Relations at Griffith University and recipient of a Discovery Early Career Research Award from the Australian Research Council (2018-2020). His research areas are authoritarianism, dictators, democratization, flawed elections, and Southeast Asian politics.

Thomas Pepinsky is associate professor of Government at Cornell University. Currently, he is working on issues relating to identity, politics, and political economy in Southeast Asia and beyond. 